\title{
Volatile-mediated interactions between phylogenetically different soil bacteria
}

\author{
Paolina Garbeva ${ }^{1}$, Cornelis Hordijk ${ }^{1}$, Saskia Gerards ${ }^{1}$ and Wietse de Boer ${ }^{1,2}$ \\ 1 Department Microbial Ecology, Netherlands Institute of Ecology (NIOO-KNAW), Wageningen, Netherlands \\ ${ }^{2}$ Department of Soil Quality, Wageningen University and Research Centre, Wageningen, Netherlands
}

\author{
Edited by: \\ Luis Raul Comolli, Lawrence \\ Berkeley National Laboratory, USA \\ Reviewed by: \\ Osnat Gillor, Ben Gurion University, \\ Israel \\ Gabriele Berg, Graz University of \\ Technology, Austria \\ *Correspondence: \\ Paolina Garbeva, Department \\ Microbial Ecology, Netherlands \\ Institute of Ecology (NIOO-KNAW) \\ Droevendaalsesteeg 10,6708 PB \\ Wageningen, Netherlands \\ e-mail: p.garbeva@nioo.knaw.nl
}

There is increasing evidence that organic volatiles play an important role in interactions between micro-organisms in the porous soil matrix. Here we report that volatile compounds emitted by different soil bacteria can affect the growth, antibiotic production and gene expression of the soil bacterium Pseudomonas fluorescens Pf0-1. We applied a novel cultivation approach that mimics the natural nutritional heterogeneity in soil in which $P$. fluorescens grown on nutrient-limited agar was exposed to volatiles produced by 4 phylogenetically different bacterial isolates (Collimonas pratensis, Serratia plymuthica, Paenibacillus sp., and Pedobacter sp.) growing in sand containing artificial root exudates. Contrary to our expectation, the produced volatiles stimulated rather than inhibited the growth of $P$. fluorescens. A genome-wide, microarray-based analysis revealed that volatiles of all four bacterial strains affected gene expression of $P$. fluorescens, but with a different pattern of gene expression for each strain. Based on the annotation of the differently expressed genes, bacterial volatiles appear to induce a chemotactic motility response in P. fluorescens, but also an oxidative stress response. A more detailed study revealed that volatiles produced by $C$. pratensis triggered, antimicrobial secondary metabolite production in P. fluorescens. Our results indicate that bacterial volatiles can have an important role in communication, trophic - and antagonistic interactions within the soil bacterial community.

Keywords: bacterial volatiles, inter-specific interactions, transcriptional responses, sand microcosm, infochemicals

\section{INTRODUCTION}

Most soil bacteria occur in multi-species communities, in which a variety of interactions influences their behavior and performance. Recent years have shown an explosion of research on "communication" between different soil bacterial species (Keller and Surette, 2006; Ryan and Dow, 2008; Shank and Kolter, 2009; Garbeva et al., 2011b). Most attention has been paid to the perception of other bacterial species via signaling compounds diffusing in liquid or semi-solid media. However, an important characteristic of most soils is the occurrence of air-filled pores. Hence, the gaseous phase forms an integral part of the natural surroundings of soil microorganisms. It has been estimated that the area of soil particles covered by microorganisms is less than $1 \%$ implying that the distance between microbial neighbors can be considerable (Young et al., 2008). Volatile molecules can act over a wider range of scale than non-volatiles as they can diffuse through both the liquid and gaseous phases of the soil (Effmert et al., 2012). Therefore, volatiles are thought to play an important role in communication and competition between physically separated soil microorganisms (Kai et al., 2009; Chernin et al., 2011; Garbeva et al., 2011a, 2014; Effmert et al., 2012).

It is well known that many soil microorganisms produce volatile organic compounds (VOC). In a recent review by Effmert et al. (2012) an overview is given of the wide variety of volatiles emitted by bacterial strains isolated from soils. From this review as well as from other papers it is clear that the spectrum of volatile compounds differs between bacterial species, even between closely related ones (Groenhagen et al., 2013; Garbeva et al., 2014). In addition, environmental conditions, in particular nutrient availability, do influence the composition of bacterial volatiles (Blom et al., 2011; Garbeva et al., 2014).

With respect to the functioning of soil microbial volatiles, most attention has been given to suppressive effects of bacterial volatiles on soil eukaryotes that are harmful to agricultural crops, e.g., plant-pathogenic fungi and plant-parasitic nematodes (Gu et al., 2007; Kai et al., 2007; Zou et al., 2007; Verginer et al., 2010; Garbeva et al., 2014). However, the role of volatiles in interactions between soil bacterial species has been hardly studied. Given the physically separated distribution of bacterial populations (microcolonies) in the porous soil matrix we hypothesize that volatiles play key roles in interspecific bacterial interactions. In the current study, our aim was to test volatile-mediated interactions between soil bacterial species under conditions that are realistic to soil conditions. To this end we applied a novel cultivation approach where we tried to mimic volatile-mediated interactions between bacteria in the rhizosphere and bacteria outside the rhizopshere. As model bacteria we selected five phylogenetically different soil isolates that do occur in natural rhizosphere communities. The main research questions we addressed were (1) Do rhizobacteria protect their "territory" against potential rhizosphere invaders 
by producing volatiles that suppress bacteria outside the rhizosphere or (2) Can bacteria outside the rhizosphere profit from the volatiles produced by rhizosphere-inhabiting bacteria? Our expectation was that rhizosphere-inhabiting bacteria will invest part of the energy obtained from metabolizing root-exudates in the production of suppressing volatiles.

\section{MATERIALS AND METHODS \\ BACTERIAL ISOLATES AND GROWTH MEDIA USED IN THIS WORK}

Collimonas pratensis Ter91 ( $\beta$-Proteobacteria), Paenibacillus sp. P4 (Bacilli) and Pedobacter sp. V48 (Sphingobacteria) have been isolated isolates from the rhizopshere of Marram grass in sandy dune soils in The Netherlands (De Boer et al., 1998, 2004); Serratia plymuthica PRI-2C strain (Y-Proteobacteria) was isolated from maize rhizosphere, The Netherlands (Garbeva et al., 2004) Pseudomonas fluorescens Pf0-1 was isolated from an agricultural soil in Massachusetts, USA (Compeau et al., 1988). All strains were pre-cultured from frozen glycerol stocks on 1/10 strength Tryptone Soya Broth agar (CMO129, Oxoid).

\section{BIOASSAY FOR TESTING THE EFFECT OF BACTERIAL VOLATILES ON PSEUDOMONAS FLUORESCENS PfO-1}

The bioassay was performed as described in the Figure S1. The top area of the glass Petri dish contained $12 \mathrm{ml}$ water-agar medium $\left(20 \mathrm{~g} \mathrm{~L}^{-1}\right.$ of Agar, $5 \mathrm{~g} \mathrm{~L}^{-1}$ of $\mathrm{NaCl}, 1 \mathrm{~g} \mathrm{~L}^{-1}$ of $\mathrm{KH}_{2} \mathrm{PO}_{4}$ and $0.1 \mathrm{~g} \mathrm{~L}^{-1}\left(\mathrm{NH}_{4}\right)_{2} \mathrm{SO}_{4} ; \mathrm{pH}$ 6.5.). This carbon-limited medium was used to represent the situation in the bulk soil where bacterial growth is limited by availability of easily degradable carbon compounds.The water-agar medium was inoculated with Pseudomonas fluorescens Pf0-1 of which $5.0 \times 10^{6}$ cells were spread over the water-agar surface. The bottom area of the glass Petri dish contained $45 \mathrm{~g}$ of sterile washed sea sand (Honeywell Specialty Chemicals Seelze GmbH, Germany) supplemented with $4.5 \mathrm{ml}$ artificial root exudates and bacterial inoculum $(3.0 \times$ $10^{6} / \mathrm{gr}$ sand) from monocultures of Collimonas pratensis Ter 91; Paenibacillus sp. P4; Pedobacter sp. V48; Serratia plymuthica PRI$2 \mathrm{C}$ or a mixture of these soil bacteria. As control treatment $P$. fluorescens Pf0-1 was exposed only to sand with artificial root exudates without bacterial inoculum. The artificial root exudates (ARE) stock solution contained $18.4 \mathrm{mM}$ glucose; $18.4 \mathrm{mM}$ fructose; $9.2 \mathrm{mM}$ saccharose; $4.6 \mathrm{mM}$ citric acid; $9.2 \mathrm{mM}$ lactic acid; $6.9 \mathrm{mM}$ succinic acid; $18.4 \mathrm{mM} \mathrm{L}$-serine; $11 \mathrm{mM} \mathrm{L}$-glutamic acid and $18.4 \mathrm{mM}$ L-alanine (C/N 10.4). To each plate $4.5 \mathrm{ml}$ of ARE working solution consisting of $1.5 \mathrm{ml}$ of stock solution mixed with $3 \mathrm{ml}$ of $10 \mathrm{mM}$ phosphate buffer ( $\mathrm{pH} 6.5$ ) was added as described in Baudoin et al. (2003). The plates were incubated at $20^{\circ} \mathrm{C}$ while packed in aluminium foil. After 3 days of incubation bacterial numbers in the top and bottom compartments were determined. $P$. fluorescens Pf0-1 cells that had developed on the top wateragar area were scraped and suspended in $3 \mathrm{ml} 10 \mathrm{mM}$ phosphate buffer ( $\mathrm{pH}$ 6.5). One hundred and fifty micro liter of this bacterial suspension was used for OD measurements and plating of serial dilutions on 1/10 TSBA medium (the remaining $2.85 \mathrm{ml}$ were used for RNA extraction, see below). For enumeration of bacteria growing in the bottom area $1 \mathrm{~g}$ of sand was taken from each plate and transferred into a $20 \mathrm{ml}$ Greiner tube. Ten milli liter of $10 \mathrm{mM}$ phosphate buffer ( $\mathrm{pH} \mathrm{6.5)} \mathrm{were} \mathrm{added} \mathrm{and} \mathrm{the} \mathrm{tubes}$ were shaken on a rotary shaker at $350 \mathrm{rpm}$ for $30 \mathrm{~min}$ at $20^{\circ} \mathrm{C}$. Subsequently, serial dilutions were plated in triplicate on $1 / 10$ TSBA. All plates were incubated at $20^{\circ} \mathrm{C}$ and bacterial colonies were counted after $48 \mathrm{~h}$.

\section{TRANSCRIPTIONAL ANALYSIS}

For total RNA extraction all suspensions retrieved from agar (see above) were diluted in sterile phosphate buffer to the same optical density $(\mathrm{OD} ; 600 \mathrm{~nm})$ to obtain equal amounts of cells for RNA extraction. The cell suspensions were centrifuged at 16,000 $\times \mathrm{g}$ for $3 \mathrm{~min}$. RNA was extracted from the cell pellets with the Artrum Total RNA Mini Kit (BIO-RAD cat\# 732-6820) according to the manufacturer's recommendations. The extracted total RNA was treated with the TURBO DNA-free Kit to remove DNA (Ambion cat\#1907).

Transcriptomic analyses were performed using high-density, multiplex $(12 \times 72 \mathrm{~K})$ microarrays designed and produced by Roche NimbleGen (Cat\# A7241-00-01). Arrays consisted of 60-mer probes covering 5735 genes, 6 probes per gene, 2 replicates. cDNA synthesis, labeling of cDNA with $\mathrm{Cy} 3$ dye and hybridization were performed by the Micro Array Department (MAD), University of Amsterdam, The Netherlands (www.microarray.nl).

Each treatment and control were performed in triplicates. The lists of differential expressed genes were extracted by comparison of each interaction with the control. The Robust Microarray Analysis (RMA)-normalized gene expression data were analyzed with the Array Star 2 software for microarray analysis (DNASTAR, Madison, Wisconsin, USA). Analysis was performed, with application of false discovery rate (FDR; Benjamini Hochberg) and multiple testing corrections.

Quantitative RT-PCR was performed to verify the gene expression detected by microarray analysis. First strand cDNA was synthesized with random hexamer primers from Invitrogen (cat\# 48190-011) using SuperScript ${ }^{\mathrm{TM}}$ Double-Stranded cDNA Synthesis kits (Invitrogen cat\#11917-010). Two $\mu \mathrm{L}$ of cDNA was subjected to real-time PCR using SYBR Green PCR master mix (Applied Biosystem). For each target gene [five differentially expressed genes: catalase; sulfotransferase, methyl-accepting chemotaxis sensory transducer, cytochrome $\mathrm{C}$ oxidase, chemotaxis sensory transducer and two non-differentially expressed control housekeeping genes: 16S rRNA and RNA polymerase (rpoB)], forward and reverse primers were designed using Primer Express software (PE Applied Biosystem, Warrington, UK). All primers used for real-time PCR were first tested using conventional PCR with DNA isolated from P. fluorescens Pf0-1. Realtime PCR was performed using a Corbett Research Rotor-Gene 3000 thermal cycler (Westburg, Leusden, The Netherlands) with the following conditions: initial cycle $95^{\circ} \mathrm{C}$ for $15 \mathrm{~min}$ and 40 cycles of: $95^{\circ} \mathrm{C}$ for $15 \mathrm{~s} ; 56^{\circ} \mathrm{C}$ for $50 \mathrm{~s}$ and $72^{\circ} \mathrm{C}$ for $50 \mathrm{~s}$. The relative expression of the genes was normalized to that of the house keeping genes.

\section{BACTERIAL VOLATILES TRAPPING AND GC/MS ANALYSIS}

For the collection of bacterial volatiles that were produced in sand containing artificial root exudates, glass Petri dishes with leads, to which a steel trap containing $150 \mathrm{mg}$ Tenax TA and $150 \mathrm{mg}$ Carbopack B (Markes International Ltd., Llantrisant, UK) could 
be fixed, were used (Figure S1b). Volatiles were collected during $72 \mathrm{~h}$ of incubation at $20^{\circ} \mathrm{C}$, traps were removed, capped and stored at $4^{\circ} \mathrm{C}$ until analysis.

Volatiles were desorbed from the traps using an automated thermodesorption unit (model Unity, Markes International Ltd., Llantrisant, UK) at $200^{\circ} \mathrm{C}$ for $12 \mathrm{~min}$ (He flow $30 \mathrm{ml} / \mathrm{min}$ ). The trapped volatiles were introduced into the GC-MS (model Trace, ThermoFinnigan, Austin, TX, USA) by heating the cold trap for $3 \mathrm{~min}$ to $270^{\circ} \mathrm{C}$. Split ratio was set to $1: 4$, and the column used was a $30 \times 0.32 \mathrm{~mm}$ ID RTX-5 Silms, film thickness $0.33 \mu \mathrm{m}$ (Restek, Bellefonte, PA, USA). Temperature program used was as follows: from 40 to $95^{\circ} \mathrm{C}$ at $3^{\circ} \mathrm{C} / \mathrm{min}$, then to $165^{\circ} \mathrm{C}$ at $2^{\circ} \mathrm{C} / \mathrm{min}$, and finally to $250^{\circ} \mathrm{C}$ at $15^{\circ} \mathrm{C} / \mathrm{min}$. The VOCs were detected by the MS operating at $70 \mathrm{eV}$ in EI mode. Mass spectra were acquired in full scan mode (33-300 AMU, $0.4 \mathrm{scan} / \mathrm{s}$ ). Compounds were identified by their mass spectra using deconvolution software (AMDIS) in combination with NIST 2008 (National Institute of Standards and Technology, USA, http://www.nist.gov) and Wiley 7 th edition spectral libraries and by their linear retention indexes (lri).

The lri values were compared with those found in the NIST and the NIOO lri database. Mass spectra and lri values for identification were also checked by analysis of pure compounds.

\section{TEST OF PURE INDIVIDUAL VOLATILES}

Several volatiles produced by Collimonas pratensis Ter91 and Serratia plymuthica PRI-2C were commercially available. A number of these compounds, namely methanthiosulfonate $\left(\mathrm{CH}_{3} \mathrm{SO}_{2} \mathrm{SCH}_{3}\right)$; S-methyl thioacetate $\left(\mathrm{C}_{3} \mathrm{H}_{6} \mathrm{OS}\right)$; dimethyldisulfide $\left(\mathrm{CH}_{3} \mathrm{~S}_{2} \mathrm{CH}_{3}\right)$ and benzonitrile $\left(\mathrm{C}_{6} \mathrm{H}_{5} \mathrm{CN}\right)$, were tested for their individual effect on $P$. fluorescens $\mathrm{Pf} 0-1$ growth. Each volatile was applied in concentrations ranging from 3, 12, 30 to $60 \mu \mathrm{mol}$ as a droplet on a filter paper on the bottom of the Petri dish. The effect of these pure compounds on $P$. fluorescens $\mathrm{Pf} 0-1$ growth was determined by CFU enumeration as described above.

\section{EXTRACTION OF SECONDARY METABOLITES FROM P. FLUORESCENS Pf0-1}

For extraction of secondary metabolites the water-agar inoculated with $P$. fluorescens Pf0-1 was removed carefully from the plate and cut in small (1-cm-diameter) pieces. These pieces were vigorously shaken in $20 \mathrm{~mL}$ of $80 \%(\mathrm{v} / \mathrm{v})$ acetone for $1 \mathrm{~h}$ at room temperature. The acetone solution was centrifuged for $10 \mathrm{~min}$ at $4000 \times$ $g$ and the acetone was evaporated under air flow. The water fraction was acidified with trifluoroacetic acid $[0.1 \%(\mathrm{v} / \mathrm{v})]$, mixed with 2 volumes of ethylacetate and shaken vigorously for $5 \mathrm{~min}$. After incubation overnight at $-20^{\circ} \mathrm{C}$ the unfrozen (ethylacetate) fraction that contains the active compounds was carefully transferred to a new flask and dried under air flow. The dried extract was dissolved in $150 \mu \mathrm{l}$ of $50 \%$ (v/v) methanol and subjected to reverse phase high pressure liquid chromatography (RP-HPLC) analysis and test for antimicrobial activity.

The antimicrobial compounds dissolved in 50\% methanol were tested for activity against the fungi Rhizoctonia solani AG2.2IIIB and Fusarium oxysporum, and the bacteria Bacillus sp. V102 and Collimonas pratensis Ter91 (as described in Garbeva et al., 2011a,b).

\section{STATISTICAL ANALYSIS}

All experiments were performed in triplicate with three independent replicates for each treatment and controls. ArrayStar 2 (DNASTAR, Madison, WI) was used for statistical analysis of differentially expressed genes applying Student's $t$-test with Benjamini-Hochberg false discovery rate correction. The statistical analyses of fungal biomass, bacterial enumeration, antagonistic tests and qRT-PCR were carried out with XLStat 2010 (Addinsoft, New York, USA) using a Student's $t$-Test. Data were considered to be statistically different at $p \leq 0.05$.

\section{RESULTS}

EFFECT OF BACTERIAL VOLATILES ON P. FLUORESCENS PFO-1 GROWTH

After 3 days of incubation, the four bacterial strains that were grown in sand containing artificial root exudates had reached similar cell densities (number of CFUs) (Figure 1). All four strains and also the mixture of strains produced volatiles in the sand microcosms (see next section), but the effect of these volatiles on the growth of $P$. fluorescens was different (Figure 2A). Volatiles produced by $C$. pratensis and S. plymuthica stimulated the growth of $P$. fluorescens, whereas volatiles emitted by Paenibacillus sp., Pedobacter sp. and the mix of all 4 bacteria did not affect $P$. fluorescens growth.

\section{VOLATILES PRODUCED BY BACTERIA GROWING IN SAND MICROCOSMS}

GC-MS analysis revealed that besides commonly known bacterial VOCs such as dimethylsulfide, 2-pentanone, 4-heptanone, 2-heptanol, and 2-undecanone, each bacterial species produced a different blend of volatiles in sand supplied with artificial root exudates (Table 1). The highest numbers of unique volatile compounds were emitted by C. pratensis and S. plymuthica. Several of these volatiles (like S-methyl thioacetate, methyl thiocyanate, dimethyl disulfide, benzonitrile) were produced by both bacteria. Paenibacillus sp. and Pedobacter sp. produced less different volatile compounds and this was also the case for the mixture of

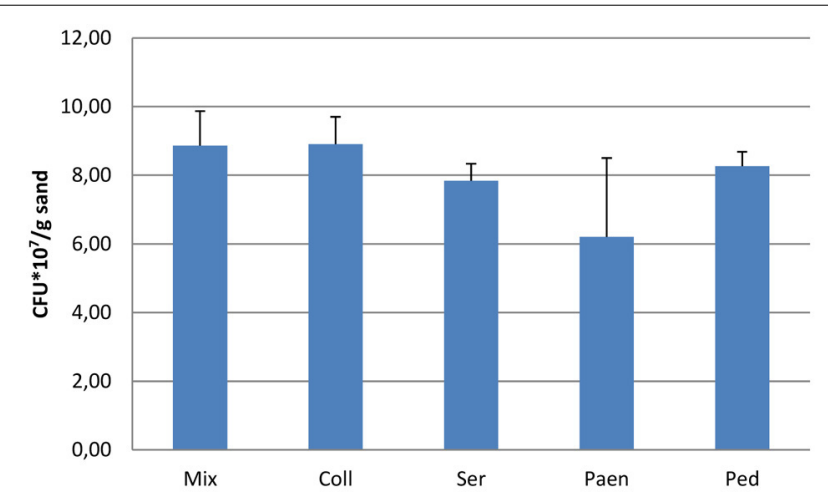

FIGURE 1 | Number of bacteria (CFUs) after 3 days of incubation in sand containing artificial root exudates. Coll- Collimonas pratensis Ter 91; Ser- Serratia plymuthica PRI-2C; Paen- Paenibacillus sp. P4; PedPedobacter sp. V48 and Mix- mix of all four bacteria. Inoculation densities were $3.0 \times 10^{6} / \mathrm{gr}$ sand. Presented values are means of three replicates and error bars indicate standard deviation. No significant differences were found between the different bacterial inoculums. 


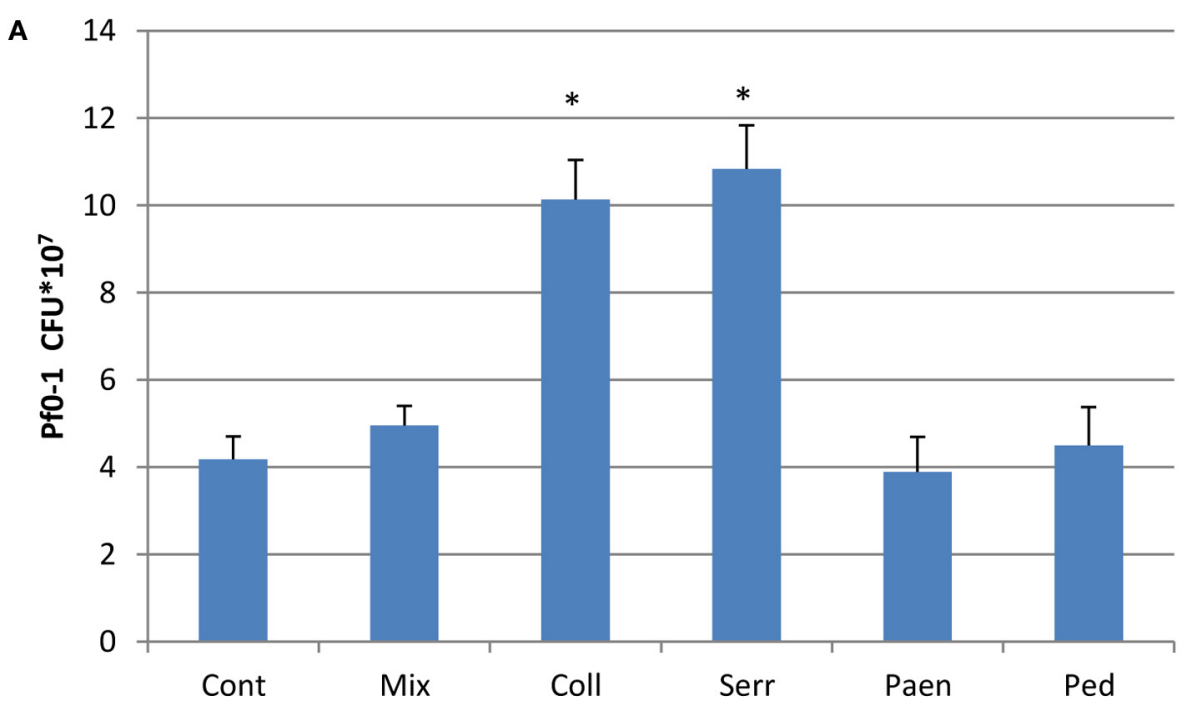

B

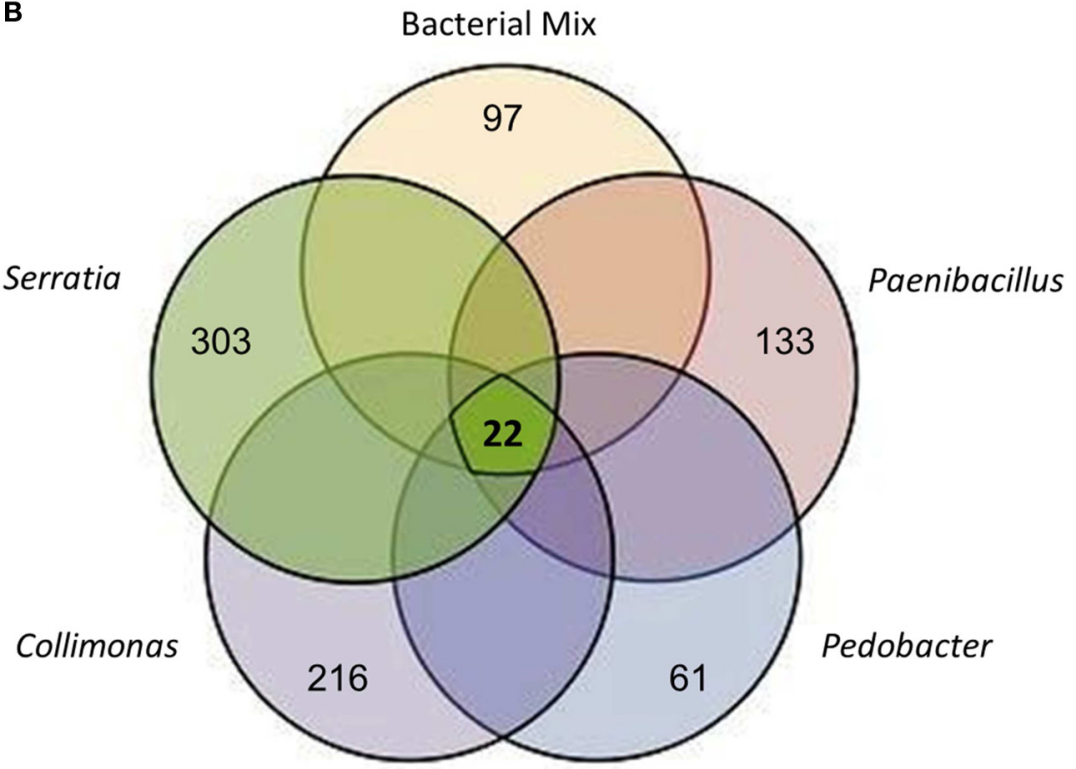

FIGURE 2 | (A) Number of $P$. fluorescens Pf0-1 colony forming units (CFUs) developed after 3 days of incubation on water-agar while exposed to volatiles emitted by different bacteria growing in sand containing artificial root exudates: Coll- Collimonas pratensis Ter 91; Serr- Serratia plymuthica PRI-2C; Paen- Paenibacillus sp. P4; Ped- Pedobacter sp. V48 and Mix- mix of all 4 bacteria. Cont- control is sand with artificial root exudates but without bacteria. Inoculation density of $P$. fluorescens PfO-1 is $5.0 \times 10^{6}$ cells. Presented data are means of three replicates, error bars indicate standard deviation and *indicates significant differences in CFUs between control and treatments $(P<0.05)$. (B) Venn diagram representing the number of differentially expressed genes in $P$. fluorescens Pf0-1 in response to volatiles emitted by different bacteria grown in sand containing artificial root exudates. The bold number in the middle of the diagram represents the common differentially expressed genes in all treatments as listed in Table 1. Other numbers indicate treatment-specific differences in gene expression: Paenibacillus sp. P4 total 133 genes (63 up-regulated and 70 down regulated); Pedobacter sp. V48 total 61 genes (50 up-regulated and 11 down regulated); Collimonas pratensis Ter91 total 216 genes (73 up-regulated and 143 down regulated); Serratia plymuthica PRI-2C total 303 genes (93 up-regulated and 210 down regulated) and bacterial mix of all 4 strains total 97 genes (31 up-regulated and 66 down regulated). four bacterial species. Interestingly, the volatiles produced by the bacterial mix included compounds that were not detected in the spectrum of volatiles produced by the different bacterial monocultures (like 1-tetradecanol, isopropyl dodecanoate, branched alcane, and unknowns).

\section{TRANSCRIPTIONAL RESPONSE OF P. FLUORESCENS Pf0-1 TO} BACTERIAL VOLATILES

Microarray-based analyses did reveal strong differences in expression of $P$. fluorescens gene when exposed to volatiles emitted by the different bacterial species (Figure 2B). Only a small set of 22 genes 
Table 1 | Volatile organic compounds produced by 4 bacterial strains growing in sterile sand containing artificial root exudates.

\begin{tabular}{lc}
\hline Compound name & RI \\
\hline PRODUCED IN ALL TREATMENTS & \\
\hline Dimethyl sulfide & $<600$ \\
2-pentanone & 688 \\
3-pentanone & 702 \\
2,4 pentadione & 779 \\
4-heptanone & 868 \\
2-heptanol & 900 \\
beta pinene & 969 \\
nonanal & 1102 \\
2-decanone & 1193 \\
decanal & 1203 \\
2-undecanol & 1301 \\
6-dodecanone & 1371 \\
Octylcyclohexane & 1443 \\
PRODUCED BY SERRATIA PLYMUTHICA PRI-2C & \\
\hline S-methyl thioacetate & 703 \\
Methyl thiocyanate & 713 \\
Dimethyl disulfide & 740 \\
1H-pyrrole & 751 \\
Methyl 3-methylbutanoate & 775 \\
Ethyl butanoate & 802 \\
Chlorobenzene & 838 \\
2,4 dithiapentane & 8872 \\
3-heptanol & 1697 \\
Dimethyl sulfone & 895 \\
Benzonitrile & 922 \\
2-octanone & 978 \\
5-dodecanone & 989 \\
2-pentadecanone & \\
PRODUCED BY COLIMONAS PRATENSIS TER91 \\
\hline
\end{tabular}

\section{PRODUCED BY COLLIMONAS PRATENSIS TER91}

2- methyl propanal

Ethenyl acetate

S-methyl thioacetate

Methyl thiocyanate

Dimethyl disulfide

3-methyl 2-pentanoene

Methyl 2-methylbutanoate

Methyl 3-methylbutanoate

3-hexanone

4-methyl 3-penten-2-one

2-acetyl 1-pyrroline

Methyl hexanoate

3-methyl 2-heptanone

Benzonitrile

7-methyl-3-methylene-1,6-octadiene (myrcene)

Ethyl hexanoate

Methyl 2-ethylhexanoate

1-methyl 4-(1-methylethyl) 1,4-cyclohexadiene (terpinene)

Methyl 2-methylbenzoate

Methyl salicylate

Methyl 3-methylbenzoate

Methyl 4-methylbenzoate

Methyl 2,6-dimethylbenzoate
Table 1 | Continued

\begin{tabular}{lr}
\hline Compound name & RI \\
\hline PRODUCED BY PAENIBACILLUS SP. P4 & \\
3-methyl-2-hexanone & 840 \\
Pentalactone & 947 \\
Hexanoic-acid & 981 \\
Carene isomer & 1007 \\
Tridecane & 1300 \\
PRODUCED BY PEDOBACTER SP. V48 & \\
1,3-butadiene, 2-methyl- & $<600$ \\
Cyclohexanone & 891 \\
Oxime methoxy phenyl & 907 \\
Benzaldehyde & 958 \\
Camphene & 940 \\
Hexanoic-acid & 981 \\
Unknown & 1145 \\
Diphenylsulfide & 1574 \\
PRODUCED ONLY IN BACTERIAL MIX & 167 \\
Sulfur dioxide & 1628 \\
Branched alcane & 1674 \\
Isopropyl dodecanoate & 1600 \\
Salicylic acid hexyl ester & \\
Unknown & $1-t e t r a d e c a n o l$ \\
\hline
\end{tabular}

RI- Linear retention index $R t x-5 \mathrm{~ms}$ column.

The table excludes volatiles that were also present in the controls (noninoculated sand with artificial root exudates).

was differentially expressed by volatiles of all bacteria, including the mixture. These genes were mainly involved in amino acid transport and-metabolism, energy production and conversion, signal transduction mechanisms, inorganic ion transport andmetabolism, secretion and cell motility (Table 2). In addition, all exposures to bacterial volatiles resulted in increased expression of a gene encoding catalase, an enzyme involved in the protection of cells against damage by reactive oxygen species. The RT-PCR analysis of 5 selected differentially expressed genes confirmed the microarray data (Figure S2). The highest number of differentially expressed genes in $P$. fluorescens was obtained when exposed to volatiles produced by $C$. pratensis, Paenibacillus sp. and S. plymuthica (Tables S1-S3) whereas volatiles emitted by Pedobacter sp. and the bacterial mix affected the expression of much less genes (Tables S4, S5). There was high similarity in the effect of volatiles of $C$. pratensis and S. plymuthica on gene expression (116 common differentially expressed genes) of $P$. fluorescens which corresponds to the high similarity in the composition of volatiles produced by these two bacteria (Tables S1, S3).

\section{EFFECT OF INDIVIDUAL VOLATILES ON P. FLUORESCENS PfO-1 GROWTH}

Four volatiles produced by C. pratensis and S. plymuthica namely methanthiosulfonate; S-methyl thioacetate; dimethyldisulfide and benzonitrile, were tested individually for their effect on $P$. fluorescens. Benzonitrile and dimethyldisulfide stimulated the growth of $P$. fluorescens growth when applied in 
Table 2 | Common genes differentially expressed in P. fluorescens Pf0-1 exposed to volatiles produced by four bacterial species and a mixture of these species in sand containing artificial root exudates.

\begin{tabular}{|c|c|c|c|c|c|c|c|}
\hline SEQ_ID & Gene description & $\begin{array}{c}\text { Fold } \\
\text { change } \\
\text { (1) }\end{array}$ & $\begin{array}{c}\text { Fold } \\
\text { change } \\
\text { (2) }\end{array}$ & $\begin{array}{c}\text { Fold } \\
\text { change } \\
\text { (3) }\end{array}$ & $\begin{array}{c}\text { Fold } \\
\text { change } \\
\text { (4) }\end{array}$ & $\begin{array}{c}\text { Fold } \\
\text { change } \\
\text { (5) }\end{array}$ & $\begin{array}{l}\text { Possible } \\
\text { function }\end{array}$ \\
\hline
\end{tabular}

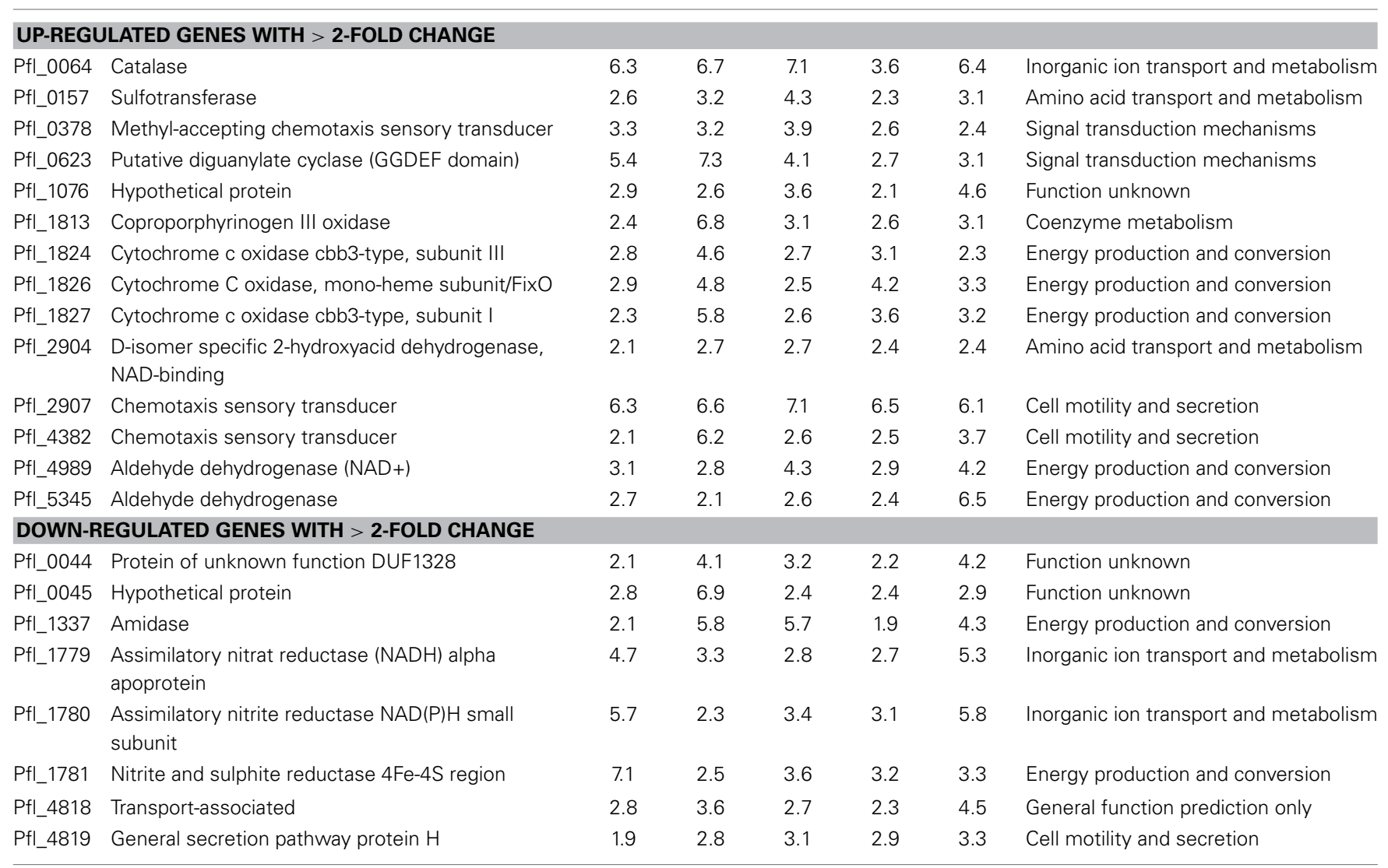

Fold change of differentially expressed genes in P. fluorescens PfO-1 exposed to volatiles produced by (1) Collimonas pratensis (2) Serratia plymuthica (3) Paenibacillus sp. (4) Pedobacter sp., and (5) Mixture of four bacterial species. The differentially expressed genes were identified using the false discovery rate (Benjamini-Hochberg) correction method with $99 \%$ confidence $(P<0.05)$.

concentrations above $3 \mu \mathrm{mol}$ (Figure S3). Methanthiosulfonate and S-methyl thioacetate did not reveal any effect on the Pf0-1 growth.

\section{EFFECT OF BACTERIAL VOLATILES ON P. FLUORESCENS PF0-1 SECONDARY METABOLITES PRODUCTION}

To test if bacterial volatiles triggered $P$. fluorescens $P f O-1$ secondary metabolites production, ethylacetate extracts were made from water-agar on which $P$. fluorescens had been grown while exposed to volatiles emitted by $C$. pratensis. Comparison of the HPLC profiles and activities of these extracts with those extracts obtained from controls revealed that $P$. fluorescens Pf0-1 produced many more secondary metabolites (11 vs. 7) with higher intensity when exposed to volatiles produced by $C$. pratensis (Figure S4). Furthermore, these extracts showed antimicrobial activity against a Gram-positive bacterium (Bacillus sp.) and the plant pathogenic fungus (Fusarium oxysporum) but did not affect growth of C. pratensis.

\section{DISCUSSION}

The role of bacterial volatiles in microbial interactions is increasingly recognized in the last years. However, most work on bacterial volatiles to date is done in vitro under nutrient-rich conditions (Beck et al., 2003; Chun et al., 2010; Kai et al., 2010; Weise et al., 2012; Kim et al., 2013) and may not be representative for the conditions that occur in the soil environment. In the present study, we developed an experimental set-up that is approaching a situation which is likely to occur in soils namely the volatile-mediated interactions between bacteria growing in the rhizosphere with bacteria present outside the rhizosphere. Since the latter are experiencing starvation conditions we hypothesized that volatiles produced by rhizosphere bacteria could act as a chemoattractant to the nutrient-richer conditions nearby. On the other hand production of volatiles by rhizospere-inhabiting bacteria could also be used to suppress other bacteria which would prevent invasion of the rhizosphere by potentially new competitors. 
It is known that bacterial volatiles can have antimicrobial activity and inhibit the growth of other microorganisms (Kai et al., 2007, 2009; Garbeva et al., 2014). However, none of the four rhizobacteria appeared to produce volatiles that were inhibiting the starved model bacterium $P$. fluorescens. It is plausible that similar to what has been reported for effects of antibiotics, bacteria are becoming highly tolerant to volatiles when they are under nutrient limitation (Nguyen et al., 2011). Volatiles emitted by C. pratensis and S. plymuthica did even stimulate Pseudomonas growth and were probably used as energy source. Some volatiles produced by these two bacteria were applied as pure substances and did also result in increased $P$. fluorescens growth. Growth of microbes in the area surrounding the rhizosphere is limited by carbon availability and, therefore, carbon-containing volatiles produced by rhizosphere microbes may be important energy resources for such microbes (Owen et al., 2007). Kleinheinz et al. (1999) revealed that P. fluorescens were able to degrade alpha-pinene released by plants and to use it as a sole energy source.

Although bacterial volatiles did not inhibit the growth of $P$. fluorescens they caused expression of genes that indicate a stress response, e.g., Pfl_0064 Catalase. It is known that catalase can be induced under conditions of oxidative stress which may have been caused by some of the volatiles (Lushchak, 2001; Kwon et al., 2010).

The genome-wide microarray-based analyses revealed that $P$. fluorescens had a different response in gene expression to volatiles emitted by the different bacterial species. Only a small set of 22 genes was differentially expressed in all treatments. Among these common differentially expressed genes were Pfl_0064 Catalase, an important enzyme in protecting the cell against damage by reactive oxygen species; Pfl_0157 Sulfotransferase, belonging to a group of enzymes that catalyze the transfer of a sulfo group from a donor molecule to an acceptor alcohol or amine; Pfl_2907 and Pfl_4382 Chemotaxis sensory transducer genes, genes that are important for regulation of bacterial chemotaxis, and Pfl_0623 Diguanylate cyclase (GGDEF domain), a gene that has been indicated to be responsible for the wrinkly spreader phenotype in P. fluorescens (Malone et al., 2007; Silby et al., 2009). The difference in transcriptional response of $P$. fluorescens to different bacterial strains appeared to reflect the composition of volatiles. C. pratensis and S. plymuthica, producing similar sets of volatiles, caused similar changes in gene expression. Many differentially expressed genes were genes involved in P. fluorescens metabolic activity, signal transduction mechanisms, cell motility and secretion.

Soil bacteria including Pseudomonas possess many twocomponent signal transduction systems that help them to adapt to fluctuations in environmental conditions (Gao et al., 2007; Rodriguez et al., 2013; Willett et al., 2013). The set of differently expressed genes involved in two-component signal transduction was not the same for the 4 volatile-producing bacterial species (Tables S1-S5) indicating that volatiles may act as an infochemicals providing information on the identity of surrounding microorganisms. Furthermore, C. pratensis and S. plymuthica triggered expression of several genes related to chemotaxis and motility indicating that part of their volatiles may act as chemoattractants guiding $P$. fluorescens to a close-by environment with nutrient input.

Recent studies revealed that inter-specific interactions between phylogenetically unrelated soil bacteria often leads to production of antimicrobial compounds (Garbeva et al., 2011a,b; Onaka et al., 2011; Hopwood, 2013). Most antimicrobial compounds are produced in growth density-dependent manner and nutrient availability has a major impact on the expression of biosynthetic genes (Sanchez et al., 2010; Van Wezel and McDowall, 2011). Our results revealed that volatiles can have an effect on secondary metabolites production by $P$. fluorescens. When exposed to volatiles emitted by $C$. pratensis, $P$. fluorescens produced secondary metabolites that had inhibiting activity against a Gram positive bacterium and a fungus but not against the Gram negative volatile producer. It is plausible that the volatiles served as energy sources and/or signal inducing secondary metabolite production. The volatile-triggered antibiotic production in $P$. fluorescens could point a strategy to combine movement (chemotaxisand motility genes) with increasing competitive strength (antibiotics) to invade into the nutrient-providing rhizosphere zone.

The volatile blend produced by soil bacteria growing in the sand microcosm containing artificial root exudates differed between different bacterial species. Several studies indicated that the numbers and spectrum of volatiles produced by bacteria depends on growth conditions and nutrient availability (Blom et al., 2011; Weise et al., 2012; Garbeva et al., 2014). Interestingly, the composition of volatiles produced by the mixture of 4 bacterial species was different from that produced by each of the bacterial monocultures which may be due to competitive interactions between the bacterial species. The blend of volatiles produced by bacterial mix had a smaller effect on the expression of genes in $P$. fluorescens than the volatiles produced by monocultures. The effect of volatiles produced by the bacterial mixture is probably more representative for the situation occurring in natural environment.

In conclusion, this work is the first to report that volatiles compounds emitted by different rhizobacteria can affect the growth and gene expression of other phylogenetically distinct and physically separated bacteria. The model bacteria $P$. fluorescens growing under nutrient limited conditions was able to sense bacterial activity based on volatile production. The results obtained here do not indicate that volatiles produced by rhizobacteria are inhibitory to the bacteria outside the rhizosphere. Bacteria outside the rhizosphere may even profit from the volatiles emitted by rhizobacteria. This work reveals novel information on the role of bacterial volatiles in long-distance microbial interactions in soil and indicates that bacterial volatiles may act as growth substrates and as infochemicals affecting gene expression, metabolism and triggering the production of other secondary metabolites in responding bacteria.

\section{ACKNOWLEDGMENTS}

This work is supported by The Netherlands Organization for Scientific Research (NWO) MEERVOUD personal grant to Paolina Garbeva (836.09.004). This is publication 5614 of the NIOO-KNAW. 


\section{SUPPLEMENTARY MATERIAL}

The Supplementary Material for this article can be found online at: http://www.frontiersin.org/journal/10.3389/fmicb.2014. 00289/abstract

\section{REFERENCES}

Baudoin, E., Benizri, E., and Guckert, A. (2003). Impact of artificial root exudates on the bacterial community structure in bulk soil and maize rhizosphere. Soil Biol. Biochem.35, 1183-1192. doi: 10.1016/S0038-0717(03)00179-2

Beck, H. C., Hansen, A. M., and Lauritsen, F. R. (2003). Novel pyrazine metabolites found in polymyxin biosynthesis by Paenibacillus polymyxa. FEMS Microbiol. Lett. 220, 67-73. doi: 10.1016/S0378-1097(03)00054-5

Blom, D., Fabbri, C., Connor, E. C., Schiestl, F. P., Klauser, D. R., Boller, T., et al. (2011). Production of plant growth modulating volatiles is widespread among rhizosphere bacteria and strongly depends on culture conditions. Environ. Microbiol. 13, 3047-3058. doi: 10.1111/j.1462-2920.2011.02582.x

Chernin, L., Toklikishvili, N., Ovadis, M., Kim, S., Ben-Ari, J., Khmel, I., et al. (2011). Quorum-sensing quenching by rhizobacterial volatiles. Environ. Microbiol. Rep. 3, 698-704. doi: 10.1111/j.1758-2229.2011.00284.x

Chun, S. C., Yoo, M. H., Moon, Y. S., Shin, M. H., Son, K. C., Chung, I. M., et al. (2010). Effect of bacterial population from rhizosphere of various foliage plants on removal of indoor volatile organic compounds. Korean J. Hortic. Sci. Technol. 28, 476-483.

Compeau, G., Alachi, B. J., Platsouka, E., and Levy, S. B. (1988). Survival of rifampin-resistant mutants of pseudomonas-fluorescens and pseudomonasputida in soil systems. Appl. Environ. Microbiol. 54, 2432-2438.

De Boer, W., Gunnewiek, P., Lafeber, P., Janse, J. D., Spit, B. E., and Woldendorp, J. W. (1998). Anti-fungal properties of chitinolytic dune soil bacteria. Soil Biol. Biochem. 30, 193-203. doi: 10.1016/S0038-0717(97)00100-4

De Boer, W., Leveau, J. H. J., Kowalchuk, G. A., Gunnewiek, P., Abeln, E. C. A., Figge, M. J., et al. (2004). Collimonas fungivorans gen. nov., sp nov., a chitinolytic soil bacterium with the ability to grow on living fungal hyphae. Int. J. Syst. Evol. Microbiol.54, 857-864. doi: 10.1099/ijs.0.02920-0

Effmert, U., Kalderas, J., Warnke, R., and Piechulla, B. (2012). Volatile mediated interactions between bacteria and fungi in the soil. J. Chem. Ecol. 38, 665-703. doi: 10.1007/s10886-012-0135-5

Gao, R., Mack, T. R., and Stock, A. M. (2007). Bacterial response regulators: versatile regulatory strategies from common domains. Trends Biochem. Sci. 32, 225-234. doi: 10.1016/j.tibs.2007.03.002

Garbeva, P., Hol, W. H. G., Termorshuizen, A. J., Kowalchuk, G. A., and De Boer, W. (2011a). Fungistasis and general soil biostasis-a new synthesis. Soil Biol. Biochem. 43, 469-477. doi: 10.1016/j.soilbio.2010.11.020

Garbeva, P., Hordijk, C., Gerards, S., and De Boer, W. (2014). Volatiles produced by the mycophagous soil bacterium Collimonas. FEMS Microbiol. Ecol. 87, 639-649. doi: 10.1111/1574-6941.12252

Garbeva, P., Silby, M. W., Raaijmakers, J. M., Levy, S. B., and De Boer, W. (2011b). Transcriptional and antagonistic responses of Pseudomonas fluorescens Pf01 to phylogenetically different bacterial competitors. Isme J. 5, 973-985. doi: 10.1038/ismej.2010.196

Garbeva, P., Voesenek, K., and Van Elsas, J. D. (2004). Quantitative detection and diversity of the pyrrolnitrin biosynthetic locus in soil under different treatments. Soil Biol. Biochem. 36, 1453-1463. doi: 10.1016/j.soilbio.2004. 03.009

Groenhagen, U., Baumgartner, R., Bailly, A., Gardiner, A., Eberl, L., Schulz, S., et al. (2013). Production of bioactive volatiles by different Burkholderia ambifaria strains. J. Chem. Ecol. 39, 892-906. doi: 10.1007/s10886-0130315-y

Gu, Y.-Q., Mo, M.-H., Zhou, J.-P., Zou, C.-S., and Zhang, K.-Q. (2007). Evaluation and identification of potential organic nematicidal volatiles from soil bacteria. Soil Biol. Biochem. 39, 2567-2575. doi: 10.1016/j.soilbio.2007. 05.011

Hopwood, D. A. (2013). Imaging mass spectrometry reveals highly specific interactions between actinomycetes to activate specialized metabolic gene clusters. Mbio 4:e00612-13. doi: 10.1128/mBio.00612-13

Kai, M., Crespo, E., Cristescu, S. M., Harren, F. J. M., Francke, W., and Piechulla, B. (2010). Serratia odorifera: analysis of volatile emission and biological impact of volatile compounds on Arabidopsis thaliana. Appl. Microbiol. Biotechnol. 88 , 965-976. doi: 10.1007/s00253-010-2810-1
Kai, M., Effmert, U., Berg, G., and Piechulla, B. (2007). Volatiles of bacterial antagonists inhibit mycelial growth of the plant pathogen Rhizoctonia solani. Arch. Microbiol. 187, 351-360. doi: 10.1007/s00203-006-0199-0

Kai, M., Haustein, M., Molina, F., Petri, A., Scholz, B., and Piechulla, B. (2009). Bacterial volatiles and their action potential. Appl. Microbiol. Biotechnol. 81, 1001-1012. doi: 10.1007/s00253-008-1760-3

Keller, L., and Surette, M. G. (2006). Communication in bacteria: an ecological and evolutionary perspective. Nat. Rev. Microbiol. 4, 249-258. doi: 10.1038/nrmicro1383

Kim, K. S., Lee, S., and Ryu, C. M. (2013). Interspecific bacterial sensing through airborne signals modulates locomotion and drug resistance. Nat. Commun. 4:1809. doi: $10.1038 /$ ncomms 2789

Kleinheinz, G. T., Bagley, S. T., St John, W. P., Rughani, J. R., and McGinnis, G. D. (1999). Characterization of alpha-pinene-degrading microorganisms and application to a bench-scale biofiltration system for VOC degradation. Arch. Environ. Contam. Toxicol. 37, 151-157. doi: 10.1007/s002449900500

Kwon, Y. S., Ryu, C. M., Lee, S., Park, H. B., Han, K. S., Lee, J. H., et al. (2010). Proteome analysis of Arabidopsis seedlings exposed to bacterial volatiles. Planta 232, 1355-1370. doi: 10.1007/s00425-010-1259-x

Lushchak, V. I. (2001). Oxidative stress and mechanisms of protection against it in bacteria. Biochemistry 66, 476-489. doi: 10.1023/A:1010294415625

Malone, J. G., Williams, R., Christen, M., Jenal, U., Spiers, A. J., and Rainey, P. B. (2007). The structure-function relationship of WspR, a Pseudomonas fluorescens response regulator with a GGDEF output domain. Microbiology 153, 980-994. doi: 10.1099/mic.0.2006/002824-0

Nguyen, D., Joshi-Datar, A., Lepine, F., Bauerle, E., Olakanmi, O., Beer, K., et al. (2011). Active starvation responses mediate antibiotic tolerance in biofilms and nutrient-limited bacteria. Science 334, 982-986. doi: 10.1126/science. 1211037

Onaka, H., Mori, Y., Igarashi, Y., and Furumai, T. (2011). Mycolic acid-containing bacteria induce natural-product biosynthesis in Streptomyces species. Appl. Environ. Microbiol. 77, 400-406. doi: 10.1128/AEM.01337-10

Owen, S. M., Clark, S., Pompe, M., and Semple, K. T. (2007). Biogenic volatile organic compounds as potential carbon sources for microbial communities in soil from the rhizosphere of Populus tremula. FEMS Microbiol. Lett. 268, 34-39. doi: 10.1111/j.1574-6968.2006.00602.x

Rodriguez, H., Rico, S., Diaz, M., and Santamaria, R. I. (2013). Two-component systems in Streptomyces: key regulators of antibiotic complex pathways. Microb. Cell Fact. 12:127. doi: 10.1186/1475-2859-12-127

Ryan, R. P., and Dow, J. M. (2008). Diffusible signals and interspecies communication in bacteria. Microbiology 154, 1845-1858. doi: 10.1099/mic.0.2008/ 017871-0

Sanchez, S., Chavez, A., Forero, A., Garcia-Huante, Y., Romero, A., Sanchez, M., et al. (2010). Carbon source regulation of antibiotic production. J. Antibiot. 63, 442-459. doi: 10.1038/ja.2010.78

Shank, E. A., and Kolter, R. (2009). New developments in microbial interspecies signaling. Curr. Opin. Microbiol. 12, 205-214. doi: 10.1016/j.mib.2009.01.003

Silby, M. W., Cerdeno-Tarraga, A. M., Vernikos, G. S., Giddens, S. R., Jackson, R. W., Preston, G. M., et al. (2009). Genomic and genetic analyses of diversity and plant interactions of Pseudomonas fluorescens. Genome Biol. 10:R51. doi: 10.1186/gb2009-10-5-r51

Van Wezel, G. P., and McDowall, K. J. (2011). The regulation of the secondary metabolism of Streptomyces: new links and experimental advances. Nat. Prod. Rep. 28, 1311-1333. doi: 10.1039/clnp00003a

Verginer, M., Leitner, E., and Berg, G. (2010). Production of Volatile Metabolites by Grape-Associated Microorganisms. J. Agric. Food Chem. 58, 8344-8350. doi: 10.1021/jf100393w

Weise, T., Kai, M., Gummesson, A., Troeger, A., Von Reuss, S., Piepenborn, S., et al. (2012). Volatile organic compounds produced by the phytopathogenic bacterium Xanthomonas campestris pv. vesicatoria 85-10. Beilstein J. Org. Chem. 8, 579-596. doi: 10.3762/bjoc.8.65

Willett, J. W., Tiwari, N., Muller, S., Hummels, K. R., Houtman, J. C. D., Fuentes, E. J., et al. (2013). Specificity residues determine binding affinity for Two-Component Signal Transduction Systems. Mbio 4:e00420-13. doi: 10.1128/mBio.00420-13

Young, I. M., Crawford, J. W., Nunan, N., Otten, W., and Spiers, A. (2008). "Microbial distribution in soils: physics and scaling," in Advances in Agronomy, Vol. 100, ed D. L. Sparks (Elsevier), 81-121. doi: 10.1016/s0065-2113(08) 00604-4 
Zou, C.-S., Mo, M.-H., Gu, Y.-Q., Zhou, J.-P., and Zhang, K.-Q. (2007). Possible contributions of volatile-producing bacteria to soil fungistasis. Soil Biol. Biochem. 39, 2371-2379. doi: 10.1016/j.soilbio.2007.04.009

Conflict of Interest Statement: The authors declare that the research was conducted in the absence of any commercial or financial relationships that could be construed as a potential conflict of interest.

Received: 17 March 2014; accepted: 25 May 2014; published online: 11 June 2014.

Citation: Garbeva P, Hordijk C, Gerards S and de Boer W (2014) Volatile-mediated interactions between phylogenetically different soil bacteria. Front. Microbiol. 5:289. doi: 10.3389/fmicb.2014.00289

This article was submitted to Terrestrial Microbiology, a section of the journal Frontiers in Microbiology.

Copyright (c) 2014 Garbeva, Hordijk, Gerards and de Boer. This is an open-access article distributed under the terms of the Creative Commons Attribution License (CC BY). The use, distribution or reproduction in other forums is permitted, provided the original author(s) or licensor are credited and that the original publication in this journal is cited, in accordance with accepted academic practice. No use, distribution or reproduction is permitted which does not comply with these terms. 